\title{
Factors Influencing the Concentration of Solanesol in Burley Tobacco*
}

\author{
by H. R. Burton, Everett Leggett and R. E. Pbillips \\ Department of Agronomy, University of Kentucky, Lexington, Kentucky, U.S.A.
}

\section{SUMMARY}

Factors influencing solanesol concentration in Burley tobacco have been investigated. A fivefold difference in solanesol concentration was found among genetic lines and the growing season effected a tenfold difference of this nonaprenol for certain tobacco genotypes. Soilmoisture deficits enhanced solanesol concentration at least fourfold. Irrigation of the stressed tobacco decreased the solanesol level. Data for the 1984 and 1985 growing seasons substantiated this observation and showed that solanesol may be a good indicator of small soil-moisture deficits. In 1984 and 1985 the solanesol concentration increased dramatically after topping for the top stalk position and there were smaller increases for the bottom and middle stalk positions. Nitrogen fertilization had only a minimal influence on solanesol concentration. The data show that it is possible to control solanesol concentration through genetic selection and, more importantly, through production practices.

\section{ZUSAMMENFASSUNG}

Es wurde untersucht, durch welche Faktoren die Solanesolkonzentration von Burley-Tabak beeinflußt wird. Verschiedene Zuchtlinien unterschieden sich in ihrer Solanesolkonzentration bis zum Fünffachen voneinander, und, bedingt durch die Witterungsverhältnisse während der Wachstumsperiode, waren in dem Gehalt

\footnotetext{
" Presented, in part, at the 39th Tobacco Chemists" Research Conference, Montreal, Canada, 1985.

This paper is published with the appropal of the Director of the Kentucky Agricultural Experiment Station 2s paper 86-3-187. The authors acknowledge financial support from the U.S. Department of Agriculture (Cooperative Agreement 58-43Y-7-0027)

Reccived: 26th February 1987 - accepted: 6th May 1988.
}

an dieser Nonaprenolverbindung bei einigen Genotypen Abweichungen bis zum Zehnfachen zu verzeichnen. Wenn es dem Boden an Feuchtigkeit mangelte, erhöhte sich der Solanesolgehalt wenigstens um das Vierfache. Die Solanesolkonzentration des durch Wassermangel gestreßten Tabaks konnte durch Bewässerung gesenkt werden. Daten, die während der Wachstumsperioden der Jahre 1984 und 1985 erhoben wurden, bestãtigten diese Beobachtungen und zeigten, $\mathrm{daB}$ der Solanesolgehalt ein guter Indikator für geringe Feuchtigkeitsdefizite des Bodens ist. In den Jahren 1984 und $1985 \mathrm{mahm}$ die Solanesolkonzentration nach dem Köpfen der Pflanzen in den oberen Blattpositionen in starkem Maße und in den mittleren und unteren Blattpositionen weniger deutlich zu. Stickstoffdūngung beeintrãchtigte die Solanesolkonzentration nur äußerst geringfügig. Aus den Untersuchungsergebnissen geht hervor, daß es möglich ist, den Solanesolgehalt des Tabaks über die Auswahl bestimmter Genotypen und vor allem über landwirtschaftliche Anbauverfahren zu regulieren.

\section{RESUME}

Cette étude a porté sur les facteurs qui jouent un rôle dans la teneur en solanesol du tabac Burley. Il est apparu que d'une lignée à l'autre, il arrivait que la concentration du solanesol varie de un à cinq; de plus, selon les conditions météorologiques caractérisant la période de croissance, il a été constaté que la teneur de certains génotypes en ce composé du nonaprénol pouvait se trouver décuplée. Lorsque le sol manquait d'humidité, la concentration du solanesol a été au moins quadruplée. L'irrigation a permis de réduire la teneur en solanesol du tabac ainsi affecté par le manque d'eau. Les valeurs relevées pendant les périodes de croissance en 
1984 et 1985 ont confirmé ces observations et montré que la teneur en solanesol était un bon indicateur d'une fajble carence en humidité du sol. En 1984 et 1985, on a observé que la teneur en solanesọl des plantes après écimage avait fortement augmenté dans les feuilles situées en position haute, mais moins nettement dans celles se trouvant au milieu ou a la base de la tige. L'addition d'engrais azoté n'a eu qu'un effet extrêmement limité sur la teneur en solanesol. Les résultats de cette étude montrent qu'il est possible de réguler la teneur en solanesol du tabac par le biais de la sélection génétique et, surtout, des procédés de culture.

\section{INTRODUCTION}

Although the chemical composition of tobacco has been studied extensively, very little is known concerning the factors which influence the concentration of many of its major constituents. This is true for solanesol, a trisesquiterpenol, which is ubiquitous in plants $(1,2)$. Solanesol, the major terpenoid in tobacco, has a concentration of approximately $3.0 \%$ in cured tobacco lamina (3-5). Even though it is a major constituent, there have been few studies designed to determine the influence of genetics, growth or agronomic practices on the concentration of solanesol in Burley tobacco (6).

Because of its concentration in tobacco, solanesol could contribute significantly to the tar yield of cigarette smoke (1). Therefore any change of solanesol concentration in tobacco lamina could result in a change in the tar delivery of a cigarette. Solanesol has been reported to be a major precursor of dipentene and, to a lesser extent, of isoprene during pyrolysis (7). Also dehydration products of solanesol (solanesenes) have been isolated from mainstream cigarette smoke (8).

In 1983, a study was initiated to determine factors which influence the concentration of solanesol in tobacco. The factors examined in this study are genotypic differences, soil moisture, nitrogen fertilization, senescence, and curing.

\section{EXPERIMENTAL}

\section{Genetic Lines}

Burley 21, low-alkaloid Burley 21, low-intermediate alkaloid Burley 21, high-intermediate alkaloid Burley 21, converter line $\mathrm{Ky} 78379$ and tobacco introduction TI 1112 were grown using practices recommended for the production of Burley at the Kentucky Agricultural Experiment Station Farm during the 1982 and 1983 growing seasons (9). The air-cured Burley tobacco was separated into four stalk positions with 3 replicates for each stalk position. The midribs were removed and the lamina was ground to pass a 40 mesh screen.
Senescence and Air-curing of Burley Tobacco

Burley tobacco (cv. Ky 14) was grown at the University of Kentucky Agricultural Experiment Station farm during the 1984 and 1985 growing seasons using recommended cultural practices (9). Three replicate samples were taken from the top, middle, and bottom stalk positions at topping and at weekly intervals until harvest. Harvest date was three weeks after topping. The samples were freeze-dried, ground to pass a 40 mesh screen, and stored at $-30^{\circ} \mathrm{C}$ until analyzed. The method of sampling during curing has been previously described (10).

\section{Water-stressed Tobacco}

Ky 14 was grown in a field experiment on a Maury siltloam soil (fine, mixed, mesic typic Paleudalfs) in 1983 and 1984 at the Spindletop Research Farm, Lexington, Kentucky. Treatments consisted of five moisture regimes, namely [1] natural rainfall, [2] $0.05 \mathrm{mPa}$ full-season irrigation at the $20 \mathrm{~cm}$ soil depth, [3] $0.05 \mathrm{mPa}$ irrigation at the $20 \mathrm{~cm}$ soil depth before topping and no irrigation after topping, [4] no irrigation until one week before topping (irrigation thereafter), and [5] no irrigation or rainfall during full season. A randomized complete-block design was used and treatments were replicated four times. Water was supplied in treatments as needed by trickle-irrigation tubes adjacent to the plants in the row. Plots in treatments 3,4 and 5 were covered with black plastic sheets. The sheets were placed between the rows (edges rolled together in the row) and tightly around each plant and stapled to exclude rainfall. Plots received uniform nitrogen application at the rate of $280 \mathrm{~kg} \mathrm{~N} /$ ha as ammonium nitrate. Tobacco transplants were set $43 \mathrm{~cm}$ apart in rows that were $16 \mathrm{~m}$ long. Each plot contained six rows spaced $1 \mathrm{~m}$ apart. Soil-water potential was monitored with tensiometers, and soil-water content in the rooting zone was measured by the neutron method (10) throughout the growing season.

Three plants were removed from each plot $42,60,67$ and 81 days after transplanting and after curing. Plants were immediately separated into laminae, midveins, and stalks and were frozen, freeze-dried, and ground to pass a $\mathbf{4 0}$ mesh screen for tissue analysis.

\section{Nitrogen-stressed Tobacco}

The Burley cultivar Ky 14 was grown in a field experiment on a Captina silt-loam soil (fine-silty, mixed, mesic typic Fragidults) in 1984 und 1985 at the Eden Shale Research Farm, Owen County, Kentucky. Treatments consisted of four nitrogen levels: $0,75,150$, and $300 \mathrm{~kg} \mathrm{~N} / \mathrm{ha}$. A randomized complete-block experimental design was used and the treatments were replicated four times. Samples were taken at topping, two weeks after topping, at harvest, and at the time of final 
cure. After sampling, laminae were composited, frozen, freeze-dried, and ground to pass a 40 mesh screen for tissue analysis.

\section{Analysis for Free Solanesol}

Ground tobacco $(0.5 \mathrm{~g}$ ) was extracted in a micro-Soxhlet extractor with methylene chloride $(20 \mathrm{ml})$ for one hour. The extract was concentrated to dryness on a steam bath, the residue dissolved in ether $(2 \mathrm{ml})$, and a $250 \mu \mathrm{l}$ aliquot transferred to a derivatization vial. The internal standard, 1,3-dimyristin [1,3-ditetradecanoyl glycerol $(1 \mathrm{mg} / \mathrm{ml})]$, was added and the solvent was removed under a stream of nitrogen. N,O-Bis(trimethyl)acetamide $(0.1 \mathrm{ml})$ and dimethylformamide $(0.1 \mathrm{ml})$ were added and the vial was capped and heated at $76^{\circ} \mathrm{C}$ for 30 minutes. After cooling to room temperature, the trimethylsilyl solanesol derivative and the internal standard were diluted to $1.5 \mathrm{ml}$ with methylene chloride and analyzed by gas chromatography. The solanesol derivative was quantified on a $6 \mathrm{ft}$. $\times 1 / 4 \mathrm{in}$. glass column packed with $1 \%$ OV 101 on $80-100$ mesh GasChrom Q. Column conditions: initial temperature $220^{\circ} \mathrm{C}$ (isothermal: 4 minutes), $6 \%$ min to $330^{\circ} \mathrm{C}$. Quantification was effected by the internal standard method. Solanesol used for the calibration standard was isolated from tobacco using the procedure described by SHBEN et al. (2). The percentage relative standard deviation for this analysis procedure was less than 5 , and the minimum-detection limit was $0.01 \mathrm{mg}$ per $\mathrm{g}$ of tobacco leaf.

\section{RESULTS AND DISCUSSION}

\section{Influence of \\ Cultivar, Leaf Position and Growing Season on Solanesol}

During 1982 and 1983, five tobacco lines and a tobacco introduction were grown at the Kentucky Agricultural Experiment Station farm to determine the influence of cultivars on alkaloid composition. Analyses of these genotypes for solanesol would indicate whether genetics contribute to the concentration of this trisesquiterpenol. Data for solanesol from these air-cured cultivars grown in 1982 are presented in Figure 1. Except for TI 1112 and $\mathrm{Ky} 78379$, the bottom stalk position generally contained the highest solanesol concentration. Again, this was not in agreement with previous studies $(2,6)$ since solanesol is generally highest in the top portion of the plant. However, the latter studies were for flue-cured varieties and grown using flue-cured production regimens. This may account for the differences observed. The lower concentrations for the top portion of the Burley plant may be due to premature harvest. This observation is corroborated by data obtained for plant maturity and solanesol content in a later section of this paper. There are genetic differences in the solanesol content of the cured lamina since the concentration varies between $0.53 \%$ and $3.10 \%$.

It is of interest to note the differences in solanesol content within the alkaloid series. A previous study has indicated that only nicotine values changed while all other constituents remained constant (12). The data in Figure 1 show that there are significantly different values for solanesol among these same alkaloid lines. Therefore, the manipulation of nicotine in tobacco by genetic means may also have an effect on the concentration of other tobacco constituents. Except for TI 1112, the stalk position which shows the least genetic contribution to solanesol concentration is the very bottom position on the plant. This may indicate that as physiological age of the lamina increases the genetic differences become less important with regard to solanesol concentration.

The concentration of solanesol can also be influenced by weather variations between different growing seasons $(1,6)$. In 1982, rainfall was favorable for Burley tobacco production. Conditions for the production of high-alkaloid Burley 21 tobacco in 1983 were inadequate since there was a rainfall deficit $(-15.86 \mathrm{~cm})$. Comparison of data between the 1982 and 1983 growing seasons indicates that there was a dramatic influence of rainfall on solanesol concentration in the lamina (Figures 2 and 3). The data show that plants which were grown under water stress contained higher amounts of free solanesol. The Burley 21 cultivar showed this effect for all stalk positions except at the very bottom of the plant. The influence of water stress on 'TI 1112 was even more dramatic since there was a tenfold difference in free-solanesol concentration when comparing the bottom stalk positions. Even for the top stalk position, there was a twofold difference in solanesol between the 1982 and 1983 growing seasons. These data not only showed the influence of water stress on free solanesol, but also the fact that the tobacco cultivars responded with varying degrees of accumulation. This again indicates that tobacco types and cultivars can yield different solanesol concentrations owing to both genetic differences and inadequate rainfall.

\section{Influence of Water Stress}

Because of the large differences in free-solanesol concentration between the 1982 and 1983 growing seasons, samples were obtained in 1983 from an independent water-stress study. If a soil-water deficit influenced free-solanesol concentration, it would be shown by these samples. Data from cured Burley tobacco for the five treatments are presented in Figure 4. There were two controls (treatments 1 and 5), one of which was exposed to natural rainfall during the growing season and the latter was grown without irrigation or natural rainfall. Free-solanesol contents in the lamina between these two treatments were not significantly different. Tobacco which had adequate soil moisture $(0.05 \mathrm{mPa})$ 
Figure 1.

Contribution of genetic line and stalk position to the solanesol concentration In 1982 [air curing; least significant difference ( $p=0.05)$ : 0.53 ].

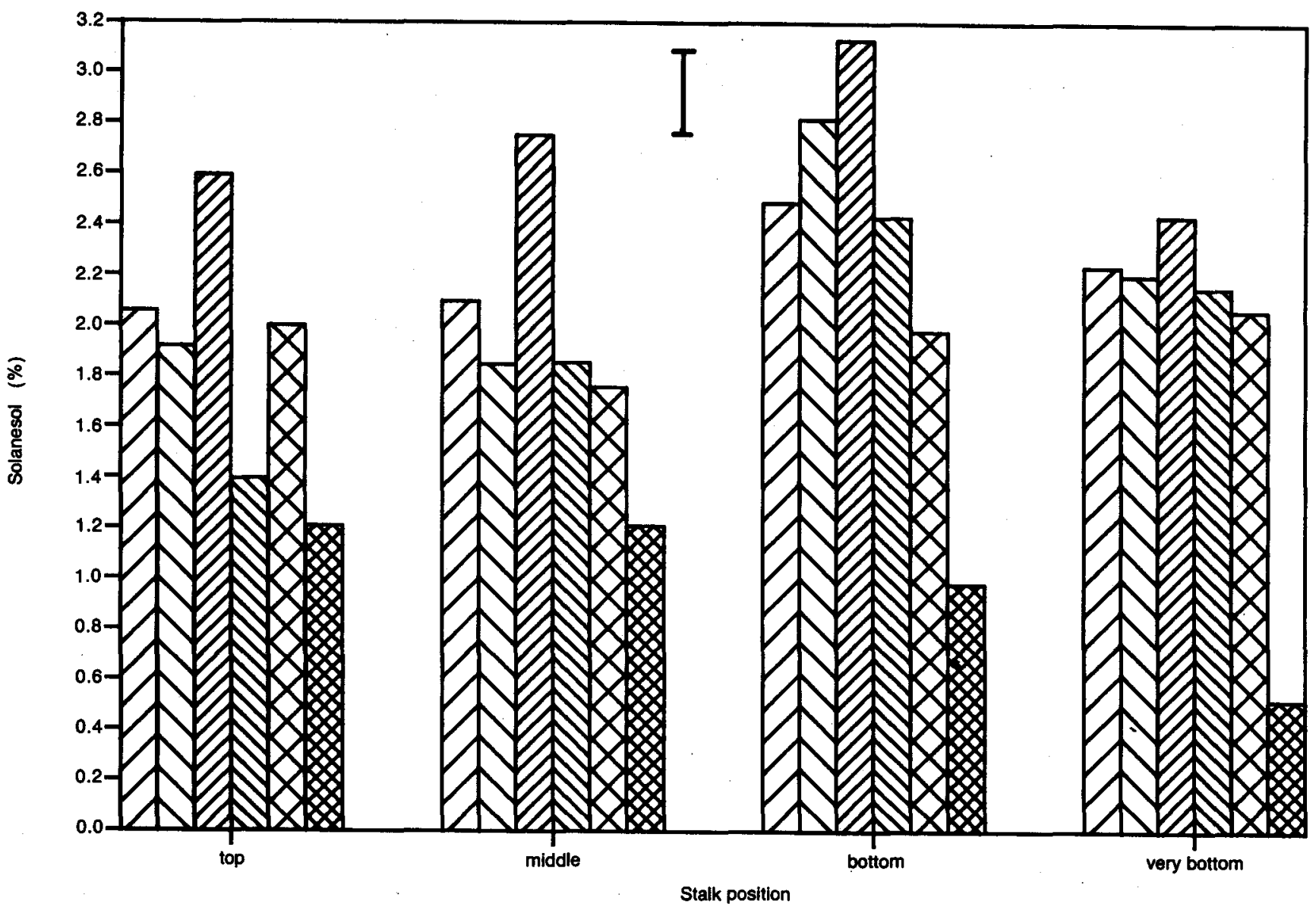

QZ7Z7): low-alkaloid Burley 21,

$\mathrm{MV \nabla}$ : low-intermediate alkaloid Burley 21,

1010पणV: Burley 21,

VIIZZZZ: high-intermediate alkaloid Burley 21 ,

ХXXXXXУ: Ky 78379 ,

: TI 1112.

Figure 2.

Contribution of the 1982 and 1983 growing seasons to the solanesol concentration in the cured lamina of highalkalold Burley 21 tobacco [least significant difference $(p=$ 0.01): 0.53].

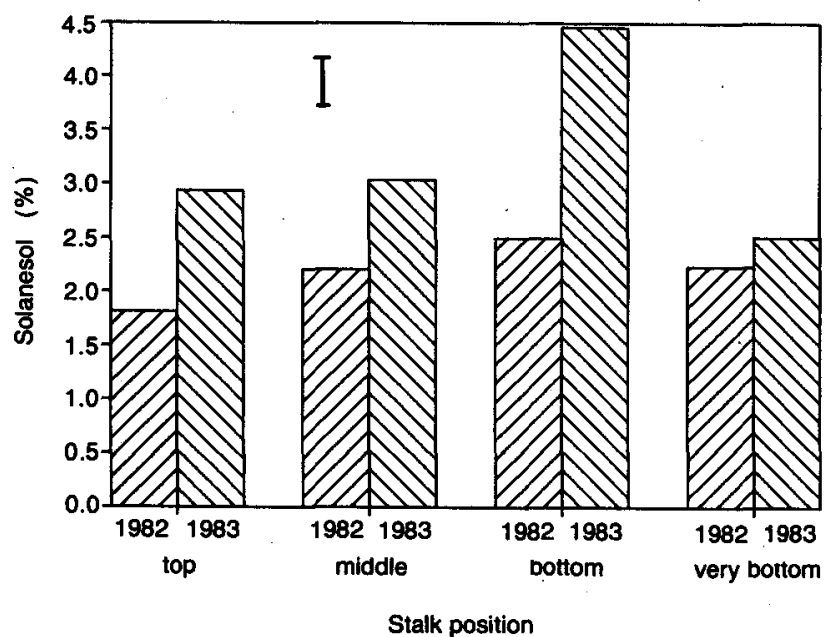

Flgure 3.

Contribution of the 1982 [least significant difference $(p-0.01)$ : 0.56 ] and 1983 [least significant difference $(p-0.01): 0.27$ ] growing seasons to the solanesol content of the cured lamina of TI 1112.

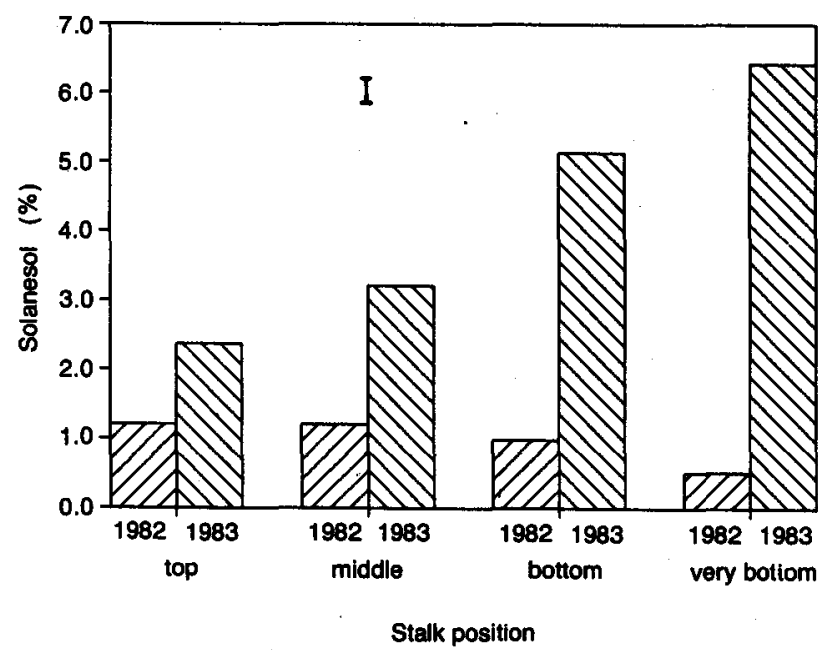


Flgure 4.

Influence of soll-molsture deficit on the solanesol concentration in 1983 alr-cured Burloy tobacco [least significant difference ( $p-0.01)$ : 0.36].

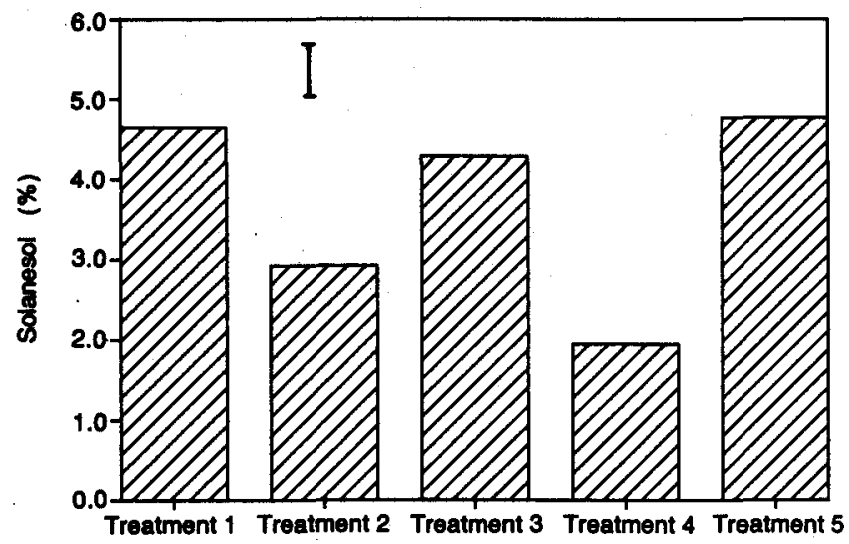

1: Natural rainfall,

2: full-season irrigation,

3: irrigation until topping,

4: irrigation until one week before topping,

5: rainfall and irrigation excluded.

for the full growing season (treatment 2) had significantly lower solanesol concentrations than the full-season water-stressed plants (treatment 5). This shows that water-stressed tobaccos (treatments 1 and 5) contained the highest amounts of free solanesol. Since there was a $15.86 \mathrm{~cm}^{-1}$ rainfall deficit in 1983 , it can be assumed there would be no difference in solanesol concentration between treatments 1 and 5 .

To determine if the low soil moisture could enhance ac-

Figure 5.

Influence of Irrigation and non-irrigation on the solanesol content of the lamina of Burley tobacco between topping and curing.

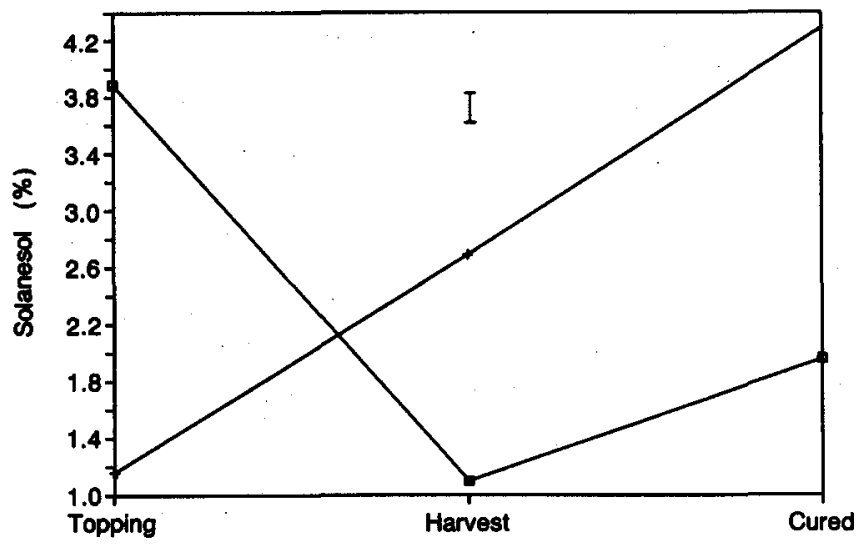

+ : irrigation until topping and no irrigation (treatment 4),

$\square$ : no irrigation and irrigation untll one week before topping (treatment 3). cumulation of free solanesol in the lamina, plants which had adequate soil moisture $(0.05 \mathrm{mPa})$ were deprived of water after topping. The air-cured tobacco which received no irrigation after topping (treatment 3 ) had slightly lower solanesol concentrations than the tobacco under full-season water stress (treatment 5) and the tobacco exposed to natural rainfall (treatment 1). Tobacco which was water stressed until topping and then irrigated (treatment 4 ) had the lowest concentrations of solanesol. This indicates that free-solanesol accumulation in the lamina is reduced under water-stress conditions since there is more than a twofold difference in the concentration of this nonaprenol.

The low solanesol concentration in air-cured treatment 4 encouraged us to quantify solanesol while the plants were under water stress, at harvest, and after air curing (Figure 5). At topping, plants which were water stressed contained $3.90 \%$ solanesol (treatment 4). After irrigation and sampling three weeks later, the solanesol concentration of these plants had decreased to $1.00 \%$. This approximately fourfold solanesol decrease was primarily a dilution effect of vegetative growth. Increased solanesol levels between harvest and final cure are most likely caused by weight loss occurring during curing. From these data one can infer that solanesol concentration in the lamina can be decreased by adequate soil moisture. When the irrigated plants were water stressed after topping (treatment 3 ), the solanesol concentration doubled within three weeks (Figure 5). The solanesol concentration increased between harvest and curing. Therefore, these data indicate that moisture availability at the time of topping is a very important factor for influencing the concentration of solanesol in the cured lamina. The solanesol concentration for these treatments also increased between harvest and curing.

\section{Influence of Senescence}

Solanesol data for the 1984 and 1985 growing seasons presented in Figure 6 show the influence of senescence on the accumulation of this trisesquiterpenol. Samples were taken from three stalk positions at weekly intervals from topping. At topping, solanesol levels were lowest for the middle and upper stalk positions. Throughout this sampling period, there was little change in solanesol for the bottom stalk position. This would seem reasonable since this stalk position would be the most senescent portion of the plant as defined by pigment concentration (11). Within three weeks after topping, solanesol concentration in the top of the plant increased dramatically, which is opposite to the plastidpigment concentration in the lamina (14). This implies that during senescence, chloroplast pigments are degraded while solanesol is accumulated. In 1984 and 1985, solanesol concentrations in the top stalk position were greater than those in the other two stalk positions within three weeks after topping but continued to increase for the duration of the sampling period. It is possible to surmise that the time of harvest is important 
Figure 8.

Influence of nitrogen fertillzation on the solanesol content of Burley lamina during the growing seasons 1984 [least significant difference $(p=0.01): 0.26$ ] and 1985 [least significant difference $(p=0.01): 0.37$.
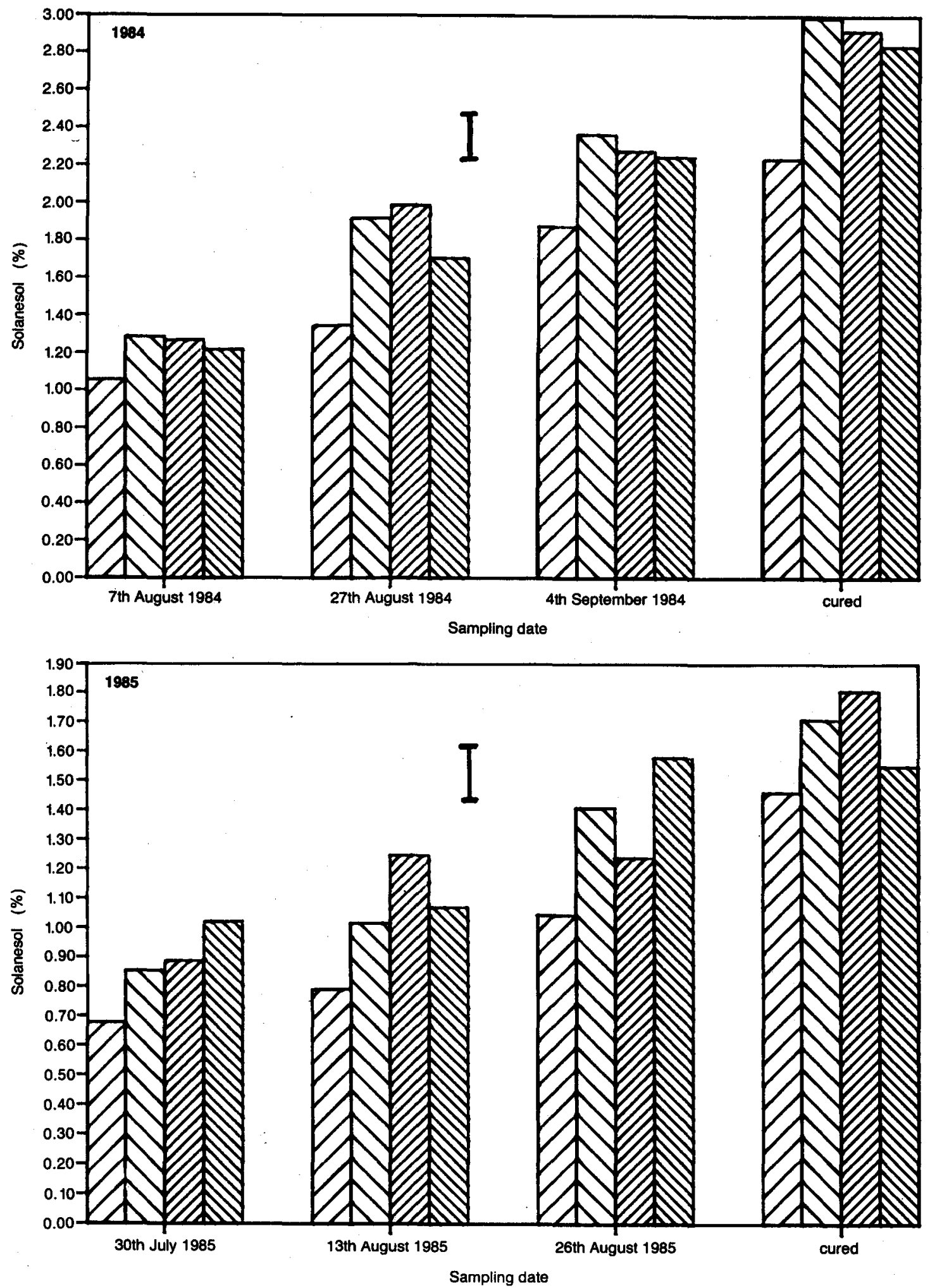
Figure 6.

Changes In the solanesol content for three stalk positions after topping during the growing seasons 1984 [least significant difference ( $p-0.01): 0.22$ ] and 1985 [least significant difference $(p-0.01): 0.36$ ].
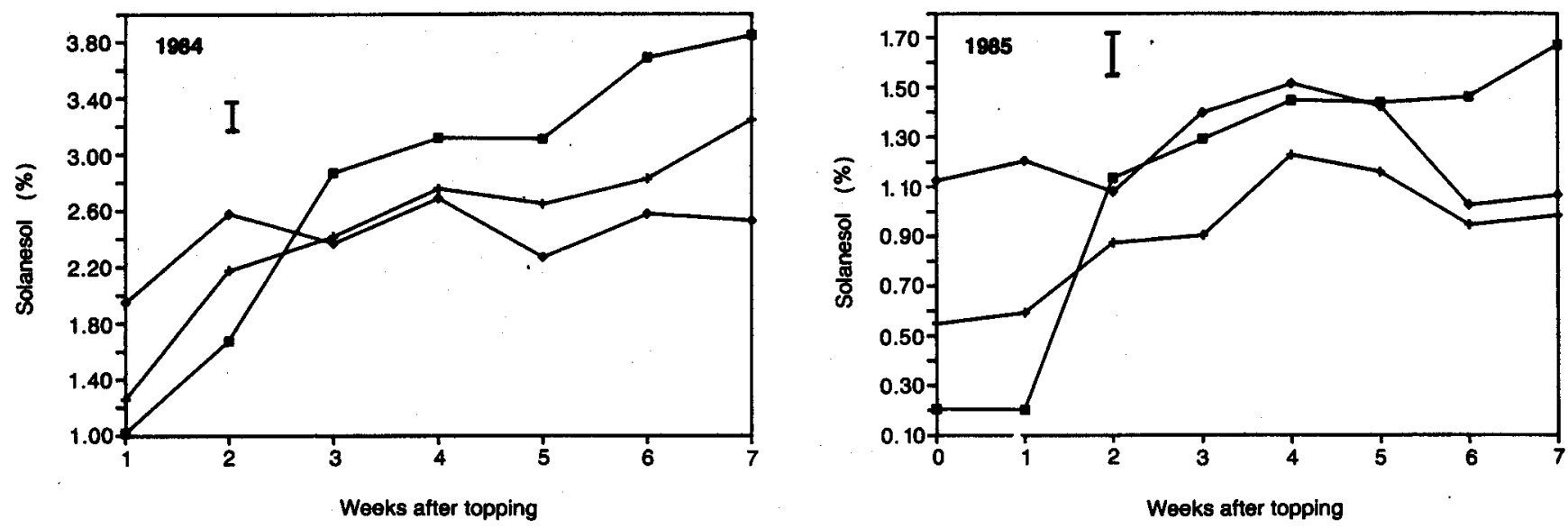

$\square$ : top stalk position, $\quad+$ : middle stalk position, $\diamond:$ bottom stalk position.

for controlling the amount of the nonaprenoid in the cured leaf.

Even though the solanesol increases within the 1984 and 1985 growing seasons paralleled each other, solanesol concentrations were three times greater in 1984 than in 1985. Even though 1984 was considered a favorable growing season there was approximately $24.9 \mathrm{~cm}$ of rainfall in comparison to $39.6 \mathrm{~cm}$ during the 1985 growing season. In 1984, from June 1 to July 6, there was $18.3 \mathrm{~cm}$ of rainfall and from July 6 to August 31, there was only $6.6 \mathrm{~cm}$ of rainfall, whereas in 1985 , there was $17.8 \mathrm{~cm}$ of rainfall from June 1 to July 6 and $21.64 \mathrm{~cm}$ of rainfall between July 6 and August 31. Tobacco was not water stressed at any time during the 1985 growing season since there was adequate rainfall throughout the growing season. The rainfall deficit in 1984 in July and August and the amount and distribution of rainfall in 1985 could explain the differences in solanesol concentration. It is of interest to note that the water stress in 1984 did not effect a significant increase in alkaloid concentration in comparison with 1985 (13). Therefore, moderate changes in soil-moisture deficits can have a significant influence on solanesol concentrations without dramatically affecting alkaloid concentrations.

\section{Influence of Curing Regimes}

Data for solanesol-concentration changes during air curing are presented in Figure 7. These data refer to the top stalk position only. This was part of a continuing study to determine the influence of curing temperatures on the composition of Burley tobacco during air curing. Solanesol concentration increased during the first two weeks of curing. This apparent increase was effected by dry-matter loss via respiration during curing.
If adjusted for dry-matter loss, there would be no significant increase in solanesol concentration.

\section{Influence of Nitrogen Fertilization}

Data for the influence of nitrogen fertilization on solanesol accumulation throughout the 1984 and 1985 growing seasons are presented in Figure 8. During the vegetative growth of the tobacco plants, the absence of nitrogen fertilization resulted in the lowest solanesol concentration. Except for the first sampling date, ni-

\section{Figure 7.}

Influence of harvest date on the solanesol concentration during air curing.

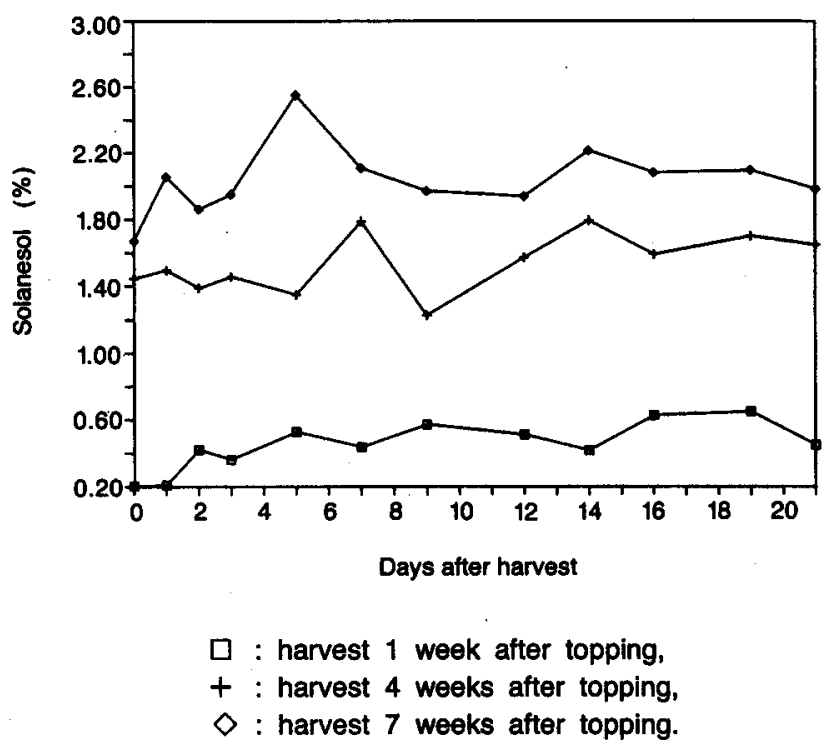


trogen fertilization effected an increase in solanesol; however, there was no significant difference for the cured samples among the three higher nitrogen-fertilization rates at any sampling date. From these data, it can be concluded that the nitrogen fertilization level was not a major factor affecting the solanesol concentration in Burley tobacco.

\section{REFERENCES}

1. Wooten, J. B.: Direct detection of solanesol in tobacco by ${ }^{1} \mathrm{H}$ and ${ }^{13} \mathrm{C}$ magic angle spinning $\mathrm{NMR}$; J. Agric. Food Chem. 33 (1985) 419-425.

2. Sheen, S. J., D. L. Davis, D. W. DeJong and J. F. Chaplin: Gas-liquid chromatographic quantification of solanesol in chlorophyll mutants of tobacco; J. Agric. Food Chem. 26 (1978) 259 $\rightarrow 262$.

3. Severson, R. F., J. J. Ellington, W. S. Schlotzhauer, R. F. Arrendale and A. I. Shepartz: Gas chromatographic method for the determination of free and total solanesol in tobacco; J. Chromatogr. 139 (1977) 269-282.

4. Court, W. A., J. M. Elliot and J. G. Hendel: Influence of applied nitrogen fertilization on certain lipids, terpenes and other characteristics of flue-cured tobacco; Tob. Sci. 28 (1984) 69-72.

5. Sakaki, 'T., K. Yamaguchi, H. Sakuma and S. Sugawara: A facile method for the determination of free and total solanesol in tobacco by gas chromatography; Jpn. Monop. Corp. Cent. Res. Inst. Sci. Pap. 124 (1982) 29-32.

6. Vidal, B., and J. Tancogne: Quantification of total solanesol in various types of tobacco - Incidence of some cultural practices on solanesol content in P.B. tobacco; Ann. Tab. 17, Section 2 (1981-1982) 93-103.

7. Grossmann, J. D., E. J. Deszyck, R. M. Ikeda and A. Bavley: A study of the pyrolysis of solanesol; Chem. Ind. (Lond.) 1962, 1950-1951.

8. Rodgman, A., L. C. Cook and S. S. Mims: The composition of cigarette smoke, V. Solanesenes; J. Org. Chem. 26 (1961) 497-501.

9. Smiley, J. H., W. C. Nesmith, L. H. Townsend, G. A. Duncan and W. W. Hourigan: Tobacco handbook ID-45; University of Kentucky, College of Agriculture, Cooperative Extension Service, Lexington, Kentucky, 1982.
10. Stone, J. F, D. Kirkham and A. H. Read: Soil moisture determination by a portable neutron scattering moisture meter; Soil Sci. Soc. Am. Proc. 19 (1955) 419-423.

11. Burton, H. R., and M. J. Kasperbauer: Changes in chemical composition of tobacco lamina during senescence and curing, I. Plastid pigments; J. Agric. Food Chem. 33 (1985) 879-883.

12. Legg, P. D., and G. B. Collins: Inheritance of percent total alkaloids in Nicotiana tabacum L., II. Genetic effects of two loci in Burley 2FX LA Burley 21 populations; Can. J. Genet. Cytol. 13 (1971) 287-291.

13. Burton, H. R., S. L. Gay and L. P. Bush: Changes in individual alkaloids of Burley tobacco after topping; presented at the 39th 'Tobacco Chemists' Research Conference, Montreal, Quebec, Canada, 1985 (submitted for publication in Tob. Sci.).

14. Burton, H. R.: Changes in chemical composition of tobacco between topping and curing - Plastid pigments; presented at the 40th .Tobacco Chemists' Research Conference, Knoxville, Tennessee, U.S.A., 1986.

\section{Acknowledgements}

The authors would like to thank L. P. Bush for providing tobacco samples from different genetic lines. The authors woould especially like to thank George Childs whose patience allowed us to analyze the large number of samples required for this study.

Authors' address:

Department of Agronomy,

University of Kentucky,

Lexington, Kentucky, 40546, U.S.A. 